\title{
PELATIHAN RATIONAL EMOTIVE BEHAVIOR THERAPY UNTUK MENINGKATKAN HARGA DIRI MAHASISWA
}

\section{RATIONAL EMOTIVE BEHAVIOR THERAPY: A TRAINING TO INCREASE STUDENTS' SELF-ESTEEM}

\author{
Narastri I. Utami, \\ Universitas Mercubuana Yogyakarta \\ narastri@mercubuana-yogya.ac.id
}

\begin{abstract}
Abstrak
Harga diri merupakan aspek yang penting dimiliki oleh mahasiswa untuk berani menghadapi tantangan. Harga diri juga dikatakan sebagai faktor penentu kesuksesan seorang mahasiswa di bidang akademiknya. Sayangnya, berdasarkan studi pendahuluan telah diketahui banyak mahasiswa cenderung membangun harga diri sebagai individu yang inferior. Penelitian ini bertujuan untuk untuk meningkatkan harga diri mahasiswa dengan pelatihan rational emotive behavior therapy. Desain eksperimen yang digunakan adalah Untreated Control Group Design with Dependent Pre-test and Post-test Samples. Hasil analisis menggunakan anava campuran menunjukkan ada peningkatan skor pada kelompok eksperimen dibanding kelompok kontrol. Pelatihan rational emotive behavior therapy memberikan $68,3 \%$ pada peningkatan harga diri mahasiswa.
\end{abstract}

Kata kunci : eksperimen, harga diri, pelatihan rational emotive behavior therapy

\begin{abstract}
Self-esteem is an important determinant of college student capacities to face life challenges. Furthermore, self-esteem has been considered as one of the most important factors in determining success and failure in education. Unfortunately, based on prior research, lots of college students tend to establish an individual identity as inferior. The aim of the present study was to carry out the training of rational emotive behavior therapy to improve the self-esteem of college students. The experimental design used Untreated Control Group Design with Dependent Pre-test and Post-test Samples. The results of the data analysis by using Mixed ANAVA shows self-esteem score the experimental group was significantly higher compared to the control group. The training of "Master Your Mind" contributed 68.3\% to the increased of college student's self-esteem.
\end{abstract}

Keywords: self-esteem, rational-emotive approach, module validation

\section{PENDAHULUAN}

Montgomery dan Cote (2008) menjelaskan bahwa bagi anak muda saat ini memasuki dunia perguruan tinggi merupakan langkah penting menuju kedewasaan. Dunia perguruan tinggi menggambarkan sebuah proses pembelajaran intensif dimana banyak pemangku kepentingan menaruh harapan. Pelaku bisnis menginginkan calon karyawan yang memiliki keterampilan unggul. Masyarakat umum membutuhkan seseorang yang berilmu dan mau mengabdi kepada lingkungan. Para orang tua mengharapkan adanya peningkatan kualitas dan kemandirian pada anaknya. Para mahasiswa itu pun sendiri berharap kuliah dapat menjadikan mereka seorang professional.

Sebagai penerus bangsa, mahasiswa dituntut untuk bersikap dan bertindak cerdas guna memperhatikan masa depan diri dan bangsanya. Banyak aspek yang perlu dikembangkan baik dalam bidang akademik maupun non-akademik. Sayangnya tidak semua mahasiswa dapat 
berperilaku seperti yang diimpikan. Ada beberapa sifat kelemahan dalam mentalitas mahasiswa yang menghambat dirinya menjadi mahasiswa yang diimpikan. Malhi (2001) berpendapat salah satu penyebab mahasiswa tidak berani menghadapi tantangan adalah karena memiliki harga diri yang rendah.

Konsep harga diri dicetuskan pertama kali pada tahun 1890 oleh William James. Ia mengatakan bahwa harga diri merupakan esensi positif dari rasa penghargaan terhadap diri sendiri yang ditumbuhkan secara konsisten saat individu berusaha meraih banyak di dalam hidupnya (Zeigler-Hill, 2013). Rasa harga diri meliputi keyakinan seperti "aku mampu”, "aku berharga" dan diikuti emosi-emosi positif atau negatif mengenai dirinya (Sharma \& Agarwala, 2014). Individu yang mengevaluasi dirinya tidak kompeten akan selalu dapat mengkritik dirinya sendiri. Individu yang merasa kompeten akan lebih bisa menerima dan menyukai dirinya sendiri. (Arslan, Hamarta \& Uslu, 2010). Harga diri berarti menemukan kondisi positif, penuh penghargaan dan rasa menyukai (Arslan, dkk, 2010), yang termanifestasi dalam berbagai bentuk seperti rasa bangga atau malu, dan pada akhirnya termanifes pada kepercayaan diri orang tersebut (Ferkany, 2008).

Peneliti melakukan studi pendahuluan untuk mendapatkan data yang kekinian dengan cara wawancara pada bulan Februari 2016 kepada empat orang dosen Perguruan Tinggi Negeri (PTN) dan Perguruan Tinggi Swasta (PTS) di Yogyakarta. Pada salah satu wawancara dosen PTN ternama di Yogyakarta, menyebutkan bahwa mahasiswanya takut bersaing dengan mahasiswa asing yang menjadi teman sekelas di fakultasnya. Sedangkan hasil dari wawancara dosen PTS, menyebutkan mahasiswanya merasa rendah diri jika harus bersaing dengan mahasiswa dari universitas lain.

Dari data tersebut terlihat bahwa perasaan tidak kompeten muncul pada mahasiswa yang berasal dari PTN maupun PTS. Fenomena ini menjadi krisis negara kita yang patut diperhatikan. Terlebih lagi pada akhir tahun 2015, Indonesia resmi mengikuti persaingan global MEA (Masyarakat Ekonomi Asean). Persaingan ini akan menjadi ancaman jika para generasi muda kita memiliki mental harga diri yang rendah. Adanya kebebasan tenaga professional asing yang akan masuk ke Negara Indonesia dapat menyebabkan para generasi muda kita mundur dikarenakan takut bersaing. Tentu hal tersebut bukanlah hasil akhir yang kita inginkan.

Oleh karenanya diperlukan pembangunan mental pada mahasiswa kita untuk berani bersaing. Di luar negeri sendiri, kesadaran akan pentingnya mengembangkan harga diri pada mahasiswa telah dilakukan di beberapa negara. Tercatat beberapa program telah dikembangkan di luar negeri untuk meningkatkan harga diri pada mahasiswanya, seperti pelatihan pengembangan harga diri dan bahasa bagi mahasiswa di Iran (Ahmadipour \& Ranjbar, 2012), program adventure therapy untuk meningkatkan harga diri mahasiswa di Kanada (Paquette, Brassard, Guerin, Chevalier, \& Beaudoin, 2014), pelatihan kepemimpinan untuk meningkatkan harga diri pada mahasiswa di China (Wong, Lau, \& Lee, 2012), dan life skill training untuk meningkatkan harga diri mahasiswa di India (Yadav \& Iqbal, 2009). 
Sayangnya di negara kita, sejauh ini belum ditemukan penelitian yang secara khusus membahas cara peningkatan harga diri untuk mahasiswa. Padahal, harga diri merupakan unsur yang mendasar dari kepribadian dan mampu membantu menjelaskan pikiran, perasaan dan perilaku seorang individu (Abdel-Khalek, Korayem, \& El-Nayal, 2012). Para peneliti juga telah menekankan bahwa harga diri merupakan aspek penting dari proses pengembangan diri seseorang. Hal ini dikarenakan harga diri menggambarkan hasil evaluasi kompetensi sehingga mempengaruhi kondisi emosi, perilaku di masa mendatang, dan penyesuaian diri jangka panjang (Nagar, Sharma, \& Chopra, 2008)

Tingkat harga diri yang memadai pada seorang mahasiswa akan membantunya meningkatkan keyakinan pada kemampuan yang dimilikinya. Harga diri akan turut meningkatkan performansi, baik dalam bidang akademik maupun non-akademik (Rendall, Wesson, Anderson, \& Bould, 2009), mempengaruhi kemampuan menjalin pertemanan dengan teman sebaya dan juga menjadi prediktor penting untuk kesuksesan di tahun-tahun berikutnya (Ahmadipour \& Ranjbar, 2012).

Penelitian ini merupakan penelitian eksperimen dengan memberikan pelatihan yang mengajarkan teknik berpikir rational emotive behavior therapy (REBT). Pelatihan tersebut akan mengajarkan cara mengubah pikiran negatif atau irasional yang dimiliki oleh seorang mahasiswa terkait harga dirinya agar menjadi pikiran yang lebih positif, berdaya dan rasional. Harga diri rendah merupakan persepsi diri yang negatif dan merupakan hasil dari kesalahan berfikir (McManus, Waite \& Shafran, 2012). Salah satu kunci peningkatan harga diri terletak pada perubahan cara berfikir (Cleghorn, 1996). Pelatihan REBT merupakan salah satu terapi yang menggunakan prinsip dasar meluruskan pikiran irasional atau yang dalam konteks sebelumnya disebut dengan kesalahan berfikir (Lea-Baranovich, Najafi, 2014).

Perubahan cara berfikir irasional menjadi rasional merupakan inti dari teori rasional-emotif yang diusung oleh Albert Ellis pada tahun 1950. Kemampuan individu untuk mengganti pikiran yang menyimpang dengan pikiran-pikiran yang obyektif dan rasional akan membuat individu mampu dalam mengendalikan dirinya (Goldfried \& Davidson, 1967). Pendekatan rasional-emotif berasumsi bahwa emosi berasal dari keyakinan, evaluasi, interpretasi terhadap situasi kehidupan yang dialami. Keyakinan atau pikiran yang irrasional akan menyebabkan terganggunya sisi emosi dan perilaku. Maka cara yang paling efektif untuk melakukan perubahan adalah dengan mengajarkan cara mengganti pikiran irrasional menjadi rasional (Corey, 2005).

Pikiran rasional adalah keyakinan yang timbul berdasar pengalaman, bersifat masuk akal dan pragmatis. Karakteristik lainnya adalah pikiran rasional bersifat fleksibel dan tidak ekstrim. Berkebalikan dengan itu, pikiran irrasional terkadang tidak berdasar pengalaman, kurang masuk akal dan tidak pragmatis. Pikiran irrasional cenderung rigid dan ekstrim (Ellis, 2004 ; Dryden and Neenan, 2004). Berdasar pada teori pendekatan rasional-emotif, seseorang dengan pikiran rasional akan merespon suatu situasi dengan perilaku yang adaptif, yakni mampu berfikir jernih, mengalami 
reaksi emosi yang sehat. Sedangkan orang yang memiliki pikiran irrasional saat menghadapi situasi yang sama akan kurang mampu berfikir jernih, terjadi disfungsi kognitif, mengalami reaksi emosi yang tidak sehat dan menunjukkan perilaku maladaptive.

\section{METODE}

Subjek penelitian adalah mahasiswa prodi $\mathrm{X}$ universitas $\mathrm{Y}$ semester enam yang terdiri dua kelas, yakni kelas A dan B. Penempatan subjek penelitian ke dalam kelompok eksperimen dan kelompok kontrol dilakukan secara non-random. Kedua kelompok eksperimen dan kontrol terdiri dari mahasiswa yang memiliki skor harga diri dalam kategori sedang. Angka skor dengan kategori sedang bergerak antara $78.65<\mathrm{x} \leq 87.35$ dengan mean 83. Pemilihan subjek dilakukan berdasar screening menggunakan skala harga diri. Selain itu peneliti melakukan kontrol terhadap tingkat inteligensi subjek dengan menggunakan tes CFIT. Dengan demikian kriteria inklusi subjek penelitian adalah sebagai berikut:

1) Mahasiswa semester enam Program Studi $X$ Universitas $Y$

2) Memiliki skor harga diri dalam kategori sedang

3) Memiliki tingkat inteligensi dalam kategori minimal rata-rata

4) Bersedia dan terlibat dalam seluruh rangkaian program penelitian

\section{Prosedur Penelitian}

Penelitian ini dibagi dalam beberapa tahapan, yaitu:

\section{a. Tahap Persiapan}

Peneliti menyusun instrument skala harga diri yang telah diuji validitas dan reliabilitas. Skala disusun berdasarkan aspek harga diri yang dikemukakan oleh Tafarodi dan Swann (2001). Tafarodi dan Swann (2011) menyebutkan harga diri terdiri atas dua aspek, yaitu: self-liking dan selfcompetence. Model penskalaan yang digunakan adalah sumated ratings (Likert) dengan lima alternatif jawaban atau respon. Skala akan digunakan sebagai alat untuk skiring mahasiswa yang memiliki permasalahan harga diri dan juga sebagai penentu peserta yang akan diberi pelatihan.

\section{b. Proses Validasi isi modul}

Validasi modul dilakukan dengan analisis rasional dan penilaian secara kuantitaf dan kualitatif. Validitas isi dilakukan oleh panel ahli yaitu terdiri dari enam orang yang merupakan dosen serta psikolog yang berkompeten dalam bidang pelatihan kepada mahasiswa serta menguasi teori pendekatan rasional-emotif.

\section{c. Proses Uji Coba di Lapangan sebagai Validasi Empirik}

Peneliti melakukan skrining terhadap mahasiswa menggunakan skala harga diri untuk mendapatkan calon peserta yang akan dibagi ke kelompok eksperimen dan kelompok kontrol. Semua peserta pada dua kelompok itu akan diberi tiga kali pengukuran yakni pretest, posttest dan 
follow up menggunakan skala harga diri. Namun yang menjadi perbedaan adalah, kelompok ekperimen diberi pelatihan sementara kelompok kontrol tidak.

\section{d. Penyusunan modul pelatihan}

Modul pelatihan disusun berdasarkan prinsip-prinsip pendekatan rational emotive behavior therapy yang dikembangkan oleh Albert Ellis (1980). Peneliti merangkum enam sesi pelatihan berdasarkan pendekatan rasional-emotif sebagai berikut:

1. Bagaimana cara kerja pikiran dalam membentuk harga diri ?

Berisi materi proses pembentukan harga diri dan teori meluruskan pikiran melalui pendekatan rasional-emotif.

2. Pikiran rasional vs irasional

Sayre (2006) meyakini bahwa seorang individu harus diajarkan cara mengevaluasi pikiran yang mereka miliki dan mengetahui apakah pikiran tersebut termasuk golongan rasional atau irasional.

3. Mind-Body Connection

Setelah memahami cara kerja pikiran, dan jenis pikiran, peserta disadarkan prinsip kedua dari pendekatan rasional-emotif yakni tiap pikiran akan mempengaruhi kondisi emosi dan gerakan tubuh seseorang.

4. Tuangkan pikiran se-simple A-B-C, yuk!

Ellis (2004) menjabarkan inti dari pendekatan rasional emotif adalah berfikir secara sistematis dan sederhana dengan lima langkah yakni A-B-C-D-E. Sesi ini akan diawali dengan penjelasan berfikir A-B-C terlebih dahulu.

5. Lanjutkan A-B-C dengan D-E!

Sesi ini mengajarkan lanjutan berfikir A-B-C-D-E dengan berfokus pada pola D dan E yakni cara membantah pikiran irasional dan cara memiliki pikiran baru yang lebih adaptif dan rasional.

6. Mendapatkan dan meyakini pola pikir (belief) baru yang lebih adaptif

Sesi terakhir dari pelatihan ini adalah sebagai evaluasi dan pemantapan dari pikiran rasional yang telah mereka pilih untuk dijadikan keyakinan baru. Di sesi ini peserta akan mengungkapkan keyakinan baru mengenai diri mereka.

\section{e. Penerapan modul kepada subjek nyata sebagai bentuk penelitian eksperimen}

Penelitian ini menggunakan desain eksperimen kuasi the untreated control group design with dependent pretest and posttest samples. Terdapat dua kelompok, yakni kelompok eksperimen yang diberikan perlakuan dan kelompok kontrol yang tidak diberikan perlakuan. Pengukuran dilakukan dengan memberikan pre-testdan post-testdengan menggunakan instrumen yang sama (Shadish, Cook,\& Campbell, 2002). Selanjutnya dalam penelitian ini ditambahkan pengukuran follow-up yang dilakukan tiga minggu setelah perlakuan. 


\section{f. Analisis Data}

Analisis data dilakukan untuk menguji perbedaan skor harga diri antara kelompok eksperimen dengan kelompok kontrol, perbedaan skor pretest, posttest dan follow up. Analsis data dilakukan menggunakan anava campuran. Teknik ini dipilih karena dapat memadukan dua sub analisis. Analisis pertama berupa within subject test yaitu pengujian perbedaan skor dalam satu kelompok (pretest,posttest, dan follow up). Analisis kedua berupa between subject test, yaitu pengujian perbedaan skor antar kelompok eksperimen dan kelompok kontrol.

\section{HASIL DAN PEMBAHASAN}

Peneliti menciptakan sebuah modul yang telah divalidasi oleh enam orang ahli dan menghasilkan skor Aiken's V yang bergerak dari 0,79 hingga 1. Azwar (2012) menyatakan bahwa skor aiken's $\mathrm{V}$ minimal 0,5 sudah dapat diterima dan dianggap memuaskan.Setelah mengetahui validitas isi modul, peneliti melakukan penelitian eksperimen untuk mengetahui pengaruh modul untuk meningkatkan harga diri mahasiswa. Penelitian ini melibatkan 15 subjek pada kelompok eksperimen (KE) dan 10 subjek pada kelompok kontrol (KK).

Data grafik 1 di bawah menunjukkan rerata skor harga diri pada pengukuran pretest, posttest dan follow up terhadap kedua kelompok. Melalui grafik tersebut diketahui bahwa kelompok eksperimen mengalami peningkatan skor harga diri setelah diberi pelatihan. Hal ini terlihat pada pengukuran posttest dan follow up. Sedangkan peningkatan skor tidak terjadi pada kelompok kontrol, baik saat post test maupun saat follow up. Hal ini menguatkan hipotesis awal bahwa modul Master Your Mind mampu meningkatkan harga diri mahasiswa.

Berikut merupakan grafik 1 peningkatan skor mean pada kelompok eskperimen dan kelompok kontrol.

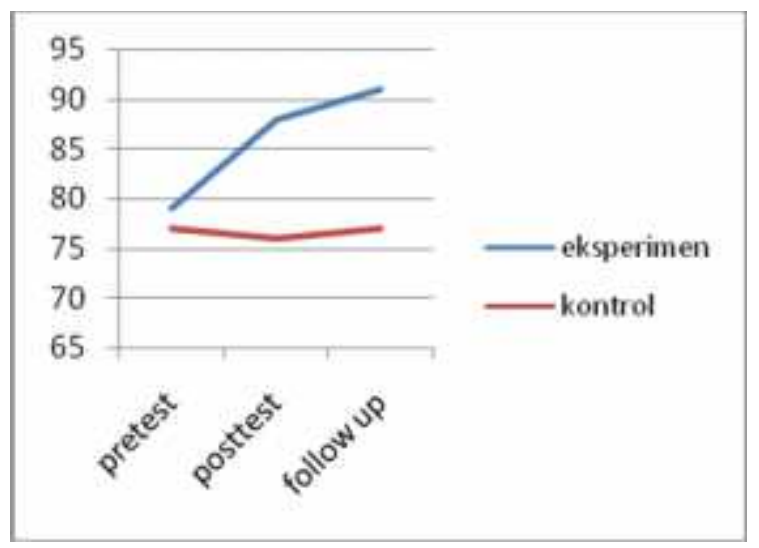

Gambar 1. Perubahan Skor Mean Skala Harga Diri Pada kelompok Eksperimen dan Kelompok Kontrol

Diketahui sumbangan efektif dari pelatihan Rational Emotive Behavior Therapy yang terlihat pada tabel dibawah ini. 
Tabel 1. Multivariate Test

\begin{tabular}{ccccc}
\hline \multicolumn{2}{c}{ Grup } & F & Sig & $\begin{array}{c}\text { Partial Eta } \\
\text { Squared }\end{array}$ \\
\hline Eksperimen & Wilks' lambda & 23.646 & $<0.01$ & 0.683 \\
Kontrol & Wilks' lambda & 0.990 & 0.896 & 0.010 \\
\hline
\end{tabular}

Nilai Partial Eta Squared pada grup eksperimen memiliki nilai =0,683; (p<0,01). Angka tersebut memiliki arti Pelatihan Master Your Mind mampu meningkatkan skor harga diri sebesar sebesar $68,3 \%$ pada kelompok eksperimen.

Noah \& Ahmad (dalam Rozubi dan Li, 2015) menyatakan bahwa selain proses eksperimen, yang perlu diperhatikan adalah manfaat yang didapat dari pelatihan. Berikut merupakan contoh pola pikir A-B-C-D-E yang dialami oleh peserta yang menunjukkan adanya manfaat pelatihan yakni perubahan pikiran irasional menjadi pikiran rasional yang dialami oleh subjek.

\begin{tabular}{|c|c|c|c|}
\hline$\underset{\text { (peristiwa) }}{\mathbf{A}}$ & $\begin{array}{c}\text { B } \\
\text { (pikiran irasional) }\end{array}$ & $\begin{array}{c}\text { C } \\
\text { (konsekuensi sikap) }\end{array}$ & $\begin{array}{c}\text { D-E } \\
\text { (bantahan dan } \\
\text { pikiran rasional } \\
\text { yang baru }\end{array}$ \\
\hline $\begin{array}{l}\text { Bimbingan } \\
\text { magang }\end{array}$ & $\begin{array}{l}\text { Kalau bimbingan, } \\
\text { saya pasti dimarahi } \\
\text { dosen karena tidak } \\
\text { bisa menjawab } \\
\text { pertanyaan. }\end{array}$ & $\begin{array}{l}\text { Menunda-nunda } \\
\text { untuk melakukan } \\
\text { bimbingan }\end{array}$ & $\begin{array}{l}\text { D : } \\
\text { Hadapi saja, dosen } \\
\text { bertanya } \\
\text { tujuannya intu } \\
\text { membuat saya lebih } \\
\text { cermat. } \\
\text { E: } \\
\text { Saya akan berusaha } \\
\text { untuk bisa menjawab. } \\
\text { Saya bisa. }\end{array}$ \\
\hline
\end{tabular}

Dalam model berfikir ABCDE, pemikiran irasional menyebabkan konsekuensi berupa emosi negatif dan perilaku yang tidak produktif (Jensen, 2008). Pendekatan rasional-emotif berguna untuk mengatasi pemikiran irasional dan menumbuhkan pemikiran rasional (Ellis, 1980) yang juga nantinya akan berdampak pada perubahan perilaku pula. Pelatihan Rational Emotive Behavior Therapy memberikan ketrampilan pada mahasiswa untuk mengubah pikiran irasional menjadi rasional dengan demikian meningkatkan rasa penghargaan terhadap diri sendiri. Seperti contoh pikiran pada tabel di atas, seorang mahasiswa awalnya memiliki pikiran irasional akan dimarahi oleh dosennya sehingga memiliki perilaku menunda-nunda untuk melakukan bimbingan. Setelah diajarkan materi inti rational emotive behavior therapy maka ia memiliki pikiran baru bahwa jika dosen memarahi karena memiliki tujuan positif. Pikiran rasional yang baru ini akhirnya dapat membuat ia merasa lebih percaya diri, mengurangi kecemasan dan berani untuk melakukan bimbingan. 
Praktik berpikir rasional yang dilakukan membuat partisipan memiliki kesadaran penuh untuk memilih makna dari suatu peristiwa yang dialaminya. Individu yang memilih untuk memberi makna yang rasional cenderung akan menimbulkan penghargaan diri yang lebih baik. Berpikir rasional memiliki pengaruh terhadap kondisi emosi dan juga perilaku partisipan. Hal ini membuat individu yang berpikir rasional akan lebih memiliki evaluasi diri yang lebih positif sehingga dapat meningkatkan harga dirinya. Nagar, Sharma \& Chopra, (2008) menjelaskan bahwa harga diri yang tinggi akan mempengaruhi kondisi emosi, perilaku di masa mendatang, dan penyesuaian diri jangka panjang.

\section{KESIMPULAN}

Berdasarkan hasil penelitian pendahuluan yang dilakukan dapat disimpulkan bahwa banyak mahasiswa yang memiliki harga diri yang rendah. Hal tersebut umumnya disebabkan karena adanya irasional belief mengenai kompetensi yang mereka miliki. Peneiliti menerapkan pelatihan Master Your Mind yang memakai teori Rational Emotive Behavior Therapy dengan tujuan untuk meningkatkan harga diri mahasiswa. Hasil penelitian menunjukkan bahwa pelatihan tersebut dapat meningkatkan skor harga diri pada kelompok yang diberi pelatihan. Hal itu dibuktikan oleh hasil analisis posttest dan follow up yang menunjukkan adanya peningkatan skor harga diri pada kelompok eksperimen setelah mengikuti pelatihan. Proses pelatihan yang diberikan membuat peserta lebih mampu untuk menerima diri sendiri, mengganti pemikiran irasional menjadi rasional, dan menumbuhkan afek positif terkait peristiwa-peristiwa yang dialaminya. Hal ini membuat kelompok eksperimen mampu mengevaluasi secara lebih baik mengenai harga dirinya. Hal yang berbeda terjadi pada kelompok kontrol, di mana skor harga diri tidak mengalami perubahan yang signifikan. Dengan demikian, hipotesis penelitian ini terbukti yaitu, pelatihan Rational Emotive Behavior Therapy dapat meningkatkan harga diri mahasiswa. Pelatihan ini memberikan kontribusi sebesar 68,3, \% terhadap peningkatanharga diri mahasiswa.

Berdasarkan hasil penelitian, ada beberapa hal yang dapat peneliti rekomendasikan. Pertama, Modul Master Your Mind dapat digunakan sebagai salah satu cara dalam meningkatkan harga diri mahasiswa. Kedua, modul ini dapat diperbanyak dan digunakan secara berkelanjutan untuk program studi di tempat peneliti melakukan penelitian eksperimen. Ketiga, penelitian berikutnya dapat melakukan penelitian untuk melakukan generalisir sejauh mana dampak Master Your Mind digunakan pada subjek yang memiliki kategorisasi berbeda dengan yang peneliti telah lakukan.

\section{DAFTAR PUSTAKA}

Abdel-Khalek, A.M., Korayem, A.S., \& El-Nayal, M.A. (2012). Self esteem among college students from four arab countries. Psychological Reports, 110(1), 297-303. doi: 10.2466/07.09.17.PR0.110.1.297-303.

Ahmadipour, T., Ranjbar, S.H. (2012). Positive change in self-esteem thorough linguistic and psyhological training among iranian kurdish university student. Theory and Practice in Language Studies, 2(7), 1403-1414. doi : 10.4304/tpls.2.7.1403-1414. 
Arslan, C., Hamarta, E. \& Uslu, M. (2010). The relationship between conflict communication, selfesteem and life satisfaction in university students. Educational Research and Reviews, 5(1), $031-034$ Didapat dari http://www.academicjournals.org/article/article1379602716Arslan\%20et\%20al.pdf

Azwar, S. (2012).Reliabilitas dan validitas. Yogyakarta: Pustaka Pelajar.

Cleghorn, P. (1996). The secrets of self esteem : A new approach for everyone. Massachusetts : Element Books.

Corey, G. (2005). Theory and practice of counseling psychotherapy. Seventh Edition. USA: Thomson Learning Inc.

Dryden, W. \& Neenan, M. (2004). The rational emotive behavioural approach to therapeutic change. London: Sage Publication, Inc.

Ellis, A. (1980). Rational-emotive therapy and cognitive behavior therapy: Similarities and differences. Journal of Cognitive Therapy and Research, Vol 4 (4), 325-340.

Ellis, A. (2004) Why rational emotive behavior therapy is the most comprehensive and effective form of behavior therapy. Journal of Rational Emotive \& Cognitive Behavior Therapy, 22 (2), 85-92.

Ferkany, M. (2008). The educational importance of self-esteem. Journal of Philopshopy of Education, 42, 119-132. doi : 10.1111/j.14679752.2008.00610.

Goldfried, M.R \& Davidson, G.C. (1976). Clinical Behavior Therapy. New York: Holt, Rinehart and Winston.

Jensen, P.E. (2008). Evaluating the ABC model of rational emotive behavior therapy theory: An analysis of the relationship between irrational thinking and guilt. Unpublished master thesis. Villanova University.

Lea-Baranovich, D., Najafi, T. (2014). Theoritical background, therapeutic process, therapeutic relationship, and therapeutic techniques of REBT and CT; and some parallels and dissimilarities between the two approaches. International Journal of Educatioon and Research, 2 (2). Didapat dari : http://www.ijern.com/journal/February-2014/13.pdf

Malhi, R. S. (2001). Importance of self-esteem. Paper presented at the International Self-Esteem and Peak Performance Conference, Hilton Petaling Jaya. Didapat dari : http://assets.csom.umn.edu/assets/71489.pdf

Montgomery, M. J. \& Cote, J. E. (2008). College as a transition to adulthood. Blackwell Handbook of Adolescence. Malden MA: Blackwell Publishing. doi : 10.1002/97780470756607.ch8

Nagar, S., Sharma, S., \& Chopra, C. (2008). Self-esteem among rural among rural adolescent girls in kangra district of himachal pradesh. Journal of Anthropologist, 10, 151-154. Didapat dari http://www.krepublishers.com/02-Journals/T-Anth/Anth-10-0-000-08-Web/Anth-10-2-00008-Abst-PDF/Anth-10-2-151-08-410-Nagar-S/Anth-10-2-151-08-410-Nagar-S--Tt.pdf.

Paquette, L., Brassard, A., Guerin, A., Chevalier, J.F., Beuadoin, L.T. (2014). Effectts of a Developmental Adventure on the Self-Esteem of College Students. Journal of Experiential Education, 37 (3), 216-231, doi : 10.1177/1053825913498372

Rendall, N. D., Wesson, C., Anderson, L., \& Bould, E. (2009). Students goal achievment : Exploring individual and situtional factors. Electornic Journal of Research in Educational 


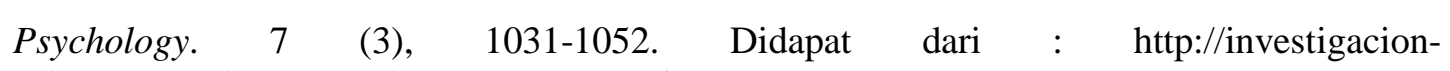
psicopedagogica.org/revista/19/Art377.pdf.

Rozubi, N., Poh Li, L. (2015). The development of psychological well-being programme based on six factormodel psychological well-being. International Journal of Information Research and Review, 2 (9), 1176-1180. Didapat dari : http://ijirr.com/sites/default/files/issuesfiles/0571.pdf

Sayre, G.W. (2006). A lesson plan in cognitive restructuring. Journal of Correctional Education. $\begin{array}{lcccc}57 & (1), & 86-95 & \text { Didapat } & \text { dari } \\ \text { http://search.proques.com/docview/229806906/15EBD3AF92094340 } & \end{array}$

Shadish, W. R., Cook, T. D., \& Campbell, D. T. (2002). Experimental and Quasi-Experimental Designs for Generalized Causal Inference. Boston: Houghton Mifflin Company

Sharma, S., \& Agarwala, S. (2014). Self esteem and collective self-esteem as predictors of depression. Journal of Behavioural Sciences, 24 (1), 21-28. Didapat dari : http://search.proquest.com/docview/1645343172/fulltextPDF?accountid=13771

Wong, M.C.S., Lau, T.C.M., \& Lee, A. (2012). The Impact of Leadership Programme on SelfEsteem and Self-Efficacy in Schol : A Randomized Controlled Trial. Journal Plos One, 7 (12). doi : 10.1371/journal.pone.0052023

Yadav, P., \& Iqbal, N. (2009). Impact of Life Skill Training on Self-Esteem, Adjustment and Empathy among Adolescents. Journal of the Indian Academy of Applied Psychology, 35, 6170. Didapat dari : http://medind.nic.in/jak/t09/s1/jakt09s1p61.pdf

Zeigler-Hill, V. (2013). The importance of self-esteem. In V. Zeigler-Hill (Ed.), Self-esteem. New York: Psychology Press. 